\title{
The Basis and the Structure of the Tertiary Socialization Field and the "Youth-Affairs" as an Autonomous Area
}

\author{
Ádám Nagy - Levente Székely
}

\begin{abstract}
Many models have been made during the study of the chronology and areas of the socialization process and thus the extrafamilial and extracurricular platforms have often been in focus. Many theories have been created about the periods preceding adulthood, i.e. youth. Now, on the borderline of the two areas a new profession is in the making, targeting youth in an extrafamilial and extracurricular context. This new area deserves thorough analysis with a focus on theoretical background since models of leisure environments outside the family and school are now on the same footing with youth education and socialization. The current study deals with leisure environment and youth. It reviews theories of socialization environments and venues, provides a grouping of them and introduces a new theory that best fits into the conceptual apparatus of the youth area and serves as a solid foundation for it. In addition, scientific and international agreements pertaining to the periods of youth will be looked at, and an attempt will be made to create a break-down by age group that is best adaptable to the extrafamilial and curricular environment. It must be stressed that the present study does not deal with the repertory of socialization themes, such as gender socialization, moral socialization, political socialization and others, but merely those environments where these take place.
\end{abstract}

Key words: tertiary socialization enviroment, youth work, youth profession, horizontal youth activities.

Many models have been made studying the chronology and areas of the socialization process ${ }^{1}$ and thus the extrafamilial and extracurricular platforms have often been in focus. A new area deserves thorough analysis with a focus on theoretical background of models of leisure environments outside the family and the school. The current study deals with the extra familiar and curricular environment, setting up the theoretical background of youth work and tries to answer the following questions: Is there any homogenious socialization field beyond the school and the family? What are its characteristics? What does the youth work field involve? It reviews the theories of socialization environments and venues, and provides a grouping of them. It must be stressed that the present study does not deal with the repertory of socialization themes, such as gender socialization, moral socialization, political socialization and others, but merely those environments where these take place. It is our objective to create a sound theoretical framework without the empirical evidence; our model will become vital after some theoretical tests have been conducted.

We were devoted to justify the existence of the tertiary socialization environment (Nagy, 1991) and the role it plays in the youth field. Because the tertiary socialization field is not the main focus of other professions and the related activities require knowledge which other professions do not fully cover. That is why we can outline the mission of the youth workers: working with young people (people and communities) in the tertiary socialization field (in resocialization situation even all of the fields). At the same time, we do not know how to approach the youth activities (primarily those carried out in the tertiary socialization environment) and what distinct characteristics they are based on and according to which criteria they can be divided into specific areas. The following study is an attempt at raising a discussion about our proposed model of youth activities.

\footnotetext{
* Ádám Nagy, Excenter Research Center, Budapest, Hungary; nagyadam@excenter.eu Levente Székely, Excenter Research Center, Budapest, Hungary; szekelylevente@excenter.eu
} 


\section{The theories of socialization environments}

The term "agencies of socialization" coined by A. Giddens (2006) refers to groups or social contexts in which socialization processes and cultural learning take place ${ }^{2}$. He asserts that certain stages of an individual's socialization might be realised through several agencies, which can be structured groups or environments where the key socialization processes take place. A. Giddens (2006) introduces four agencies of socialization: the family, peer groups, school/the workplace and mass communication devices, but also adds that in fact there are as many agencies of socialization as groups or social situations in which an individual spends a considerable period of his life ${ }^{3}$.

Other models differentiate only two environments of socialization. The first one is the family, generally referred to as early socialization or the primary or early environment of socialization. The family as a small, informal group is the first source of patterns, the scene of the first "we-experience" where the individual's habits and behaviors ${ }^{4}$ are formed. The second one is the school, where late, or secondary (chronologically and not in order of importance) socialization takes place.

Socialization in the school can be examined from the following perspectives: that of child peers, the class as a social environment, and that of the teachers. T. Parsons - R. F. Bales (1995) also distinguish between primary socialization in the early years when the basic structure of personality is formed and secondary socialization when social patterns are acquired in an institutionalised system (Parsons Bales, 1955). According to another theory derived from this one, the most important environments of secondary socialization are the school, peer groups and the media (Bodonyi et al., 2006).

Yet other theories propose a tripartite system with the family being the scene of primary socialization, the kindergarten and school those of secondary socialization and the workplace that of tertiary socialization: "secondary socialization refers to learning processes in groups of the same rank and takes place during childhood ${ }^{5} \ldots$ tertiary socialization is linked to adulthood, the period after school studies are completed, or more precisely to the years of active working life" (Kiss, 2002; Szabó, 2003). During the study of the chronological order of socialization environments in which he was examining whether there is a recession in the use of obscene language after childhood, S. Czeglédi (manuscript) defines secondary socialization as overlapping with childhood and regards tertiary socialization as the period of employment and active work ${ }^{6}$. In further classifications the family is the environment of primary socialization, obligatory (elementary) schools are that of secondary socialization, while colleges and universities are the scenes of tertiary socialization when the individual is preparing for a chosen career. C. Dupcsik (www.enc.hu) agrees that tertiary socialization involves training for a vocation or a profession.

Some research outlines a structure of four socialization environments: the family is defined as the scene of primary socialization, when basic norms and rules are acquired; the kindergarten and the school as scenes of secondary socialization; career socialization is defined as tertiary (secondary and tertiary education, and training for work); and the workplace is the environment of quaternary socialization. L. Trencsényi (2006) classifies the socialization environments according to the organization that carries out the task of teaching and thus differentiates natural communities and learning environments (family, relatives, neighbors), state institutions (children's surgery, nursery, kindergarten, boarding school, advisory centre for education, centre for child well-being, children's home, crisis care home, youth detention centre, youth prison, foster home, art school, cultural centre institution with multiple purposes, cultural house, cinema, library, theatre, museum, concert hall, dance house, stadium), as well as service providers (childcare, youth entertainment facilities - arcades - disco, extracurricular courses, training courses (language school, driving school, dance school), swimming pool, sports centre-gym) and civil initiative (churches, organizations for children and adolescents, sports associations, cultural associations, art associations). The introduction of educational media (children's magazines, children's books, radio, TV, the Internet) is an advanced element in L. Trencsényi's (2009) four-partite division ${ }^{7}$. He calls into doubt the generally highlighted 


\section{Acta Technologica Dubnicae \\ volume 2, 2012, issue 2}

and exclusive role in secondary socialization of "traditional" educational institutions that are historically not so old since they developed at the time of social modernization (Trencsényi, 2009).

Another division defines seven categories: childhood family, adult family, school, peer groups, mass communication, workplace, and other socialization environments (e.g. church and civil communities) (Vukovich, 2006). T. Kozma (1999) also reviews socialization environments and discusses each segment in detail; however, he does not apply a unified approach to the examination of the extrafamilial and curricular domains. He claims that the school is the environment of formal education, while the family, the neighbours, the workplace, the army, politics, religion and the media are those of non-formal and informal education.

Some other theories interpret socialization environments in relation to special groups and not general life situations. C. Bodó (ww.adatbank.transindex.ro) studies the issue from the perspective of minorities, who learn Hungarian during secondary or tertiary socialization. "Adult speakers also use Hungarian during the tertiary linguistic socialization of teenagers, since young people at this stage are seen by the community as adults, individuals being initiated in the world of work, with whom the linguistic code characteristically used in typical community activities, i.e. the local Hungarian dialect, is regarded as adequate" (Bodó, www. adatbank.transindex.ro). E. Szabó (2003) applies the terms secondary and tertiary linguistic socialization to penal institutions.

A shared feature of the above theories is that the family (relatives) is defined as the primary environment of socialization, where private relationship patterns and communication skills develop, identity is defined, and basic behavioral (e.g. health behavioral) habits are formed. Learning takes place through personal experience: the persons involved in this environment cannot be substituted and the fundamentals of the individual's interpretation of the world are created at this stage (these are very difficult to alter later on). The most important scenes of the secondary socialization are kindergartens and schools the aim of which is to acquire all the information, skills and values regarded by the society as important (sense of duty, reliability, accuracy, etc.). Secondary socialization occurs at a later stage of development, when new interpretations of the world appear, showing new sections of society and it introduces new hierarchies. In this environment - in contrast to the family, where mostly everything worked at a "subjective" level - individuals are primarily assessed according to their characteristics, and expectations and norms are becoming increasingly abstracted from other people. Cooperation with others must be learnt, expectations of others must be met and new rules of behavior are needed (sharing, competing).

With regard to the framework of interpretation, some of the theories (e.g. Giddens, Kozma) focus on a given stage of life and examine the related places, life situations and social time as its imprints, while others analyze and describe environments and main socialization stages of the individual's development (e.g. Parsons, Kiss, Szabó, Dupcsik, Czeglédi). However, there are differences between schools based on developmental stages and also between those analysing a given social time (differences often occur within one particular school), with regard to their terminology (using words such as environment, scene, domain, group, etc.) and the number of environments (two, three, four) they define. Even similar schools differ in what these environments are - if there are more than two and what their main drivers and postulations are. Thus, not all of these theories include a tertiary socialization environment, and even those that do differ in defining it (most of them refer to career socialization and preparing for work, but there is a number of exceptions) and in establishing if tertiary socialization has additional elements. The basis, conceptual background, reason and explanation found in literature are predominantly mainly based on conjecture and declarations (what is more, the same term is often used to denote different notions) instead of deduction and inference.

With regard to socialization beyond the family and the school, it is of key importance whether prior to adulthood the environment beyond the school and the family can be treated as a homogenous entity. It must also be established if the areas involved have any shared characteristics, and, if they do, what characteristics are distinct to all of these areas and at the same time they must be distinguished from 


\section{Acta Technologica Dubnicae \\ volume 2, 2012, issue 2}

primary and secondary environments ${ }^{8}$. Another question is if peer groups play a synthesizing role and if they can be defined as an environment or only as an additional group (in order to avoid the confusion of concepts, a qualitatively new socialization interface will from now on be referred to as an environment or a (macro) domain, and those that are only new in regard to their content - e.g. if we enter a new workplace or group - will be called a scene or a group.). An interesting proposition is if relationships, friends, peers and loves differ in their essence to relationships in the family and the school.

\section{Tertiary socialization environment}

Simply defined, free time is the period of an individual's day when he does what he wants. Two general approaches exist: free time can be understood as the time left over after work is finished and everyday needs (meals, daily errands, workplace- and school-related activities) are satisfied (left-over time approach) or the time (and use of the time) when an individual can be engaged in free time activities (activity approach). A distinction can also be made between objective and subjective free time: objectively speaking, e.g. Sunday can be seen as free time, however, if someone feels their duty to do work around the garden, it is not free time in a subjective sense (Gábor, 2000; Gábor, www.ifjusagsegito.hu; Furlong et al., 2000). Fundamentally, only subjective time is real free time, i.e. when the individual feels that he is in control and free of any external obligation. This means that free time is not defined by time and activity but by the individual. That is, free time is a personal commitment rather than an opportunity presented by circumstances. Free time is the scene related to private life, belonging to a group and consumption ${ }^{9}$.

Since the strength of socialization is determined by the time and intensity of participation (Vukovich, 2006), we can use the term environment only when an individual spends sufficient time (and intensely enough) - without these a scene can certainly not be called a socialization environment (just socialization elements, of which we can find dozens or hundreds). There are at least three places where a young person spends sufficient time, which can be divided into at least three impact groups in the present context: the family, the school (work) and the free time (see also research on social time: Demetrovics et al., 2010; Szapu, 2002; Szabó - Bauer, 2002, 2005, 2009; Gábor, 2000; Gábor, www.ifjusagsegito.hu; Furlong et al., 2000, etc.). Thus, today a third one can be added to the primary and secondary socialization environments ${ }^{10}$ : "a new socialization group agency, the peer group, can be added to the family, first complementing it, and later providing a counter-pattern" (Csepeli, 2006). While the impact of the traditional institutions of socialization (family, school) is weakened (Mátóné, 2009), the importance of a peer group ${ }^{11}$ as a platform of interaction is increased (Váriné, in Somlai, 1975).

The activities in peer groups share many characteristics with those in the family and the school, but they also differ in many respects. "The peer group is the single social scene where a young person can reckon on relationships based on equality and where, he does not experience one-sided dependence from another individual, such as a parent or a teacher" (Csepeli, 2006, p. 406). While in the family the prescribed norms are obedience and authoritarian love, the peer group operates on the basis of cooperation and mutual agreement (Piaget, 1995, p. 40). The essence in the peer group phenomenon is not the seemingly deviant content but the process in which an individual takes voluntary action which is also determined by the community, and in conforming to the group steps outside the scope of individual interests. Informal groups are quintessential to the individual (Csepeli, 2006).

The table below (Table 1) is an attempt to sum up the similarities and differences between the three environments that outline a unified tertiary socialization environment. It can be seen that some of the characteristics of the proposed tertiary environment are shared by the other two, while there are some distinct characteristics that set it apart from them. From now on we will call this area tertiary socialization (free time) environment, within which we will differentiate between generally applicable 


\section{Acta Technologica Dubnicae \\ volume 2, 2012, issue 2}

scenes of socialization (neighbors, etc.) and special scenes applicable only to certain individuals or groups: church, army. However, these scenes will not be analysed in depth in the current paper.

\begin{tabular}{|c|c|c|c|}
\hline Characteristics & Family & School & $\begin{array}{l}\text { Extrafamilial and curricular } \\
\text { (mainly free-time) activities }\end{array}$ \\
\hline $\begin{array}{l}\text { Main characteristics, } \\
\text { organizational } \\
\text { principles }\end{array}$ & $\begin{array}{l}\text { Main characteristics: } \\
\text { given. } \\
\text { Organizational } \\
\text { principle: } \\
\text { unconditional. }\end{array}$ & $\begin{array}{l}\text { Main characteristics: } \\
\text { obligatory. } \\
\text { Organizational principle: } \\
\text { conditional. }\end{array}$ & $\begin{array}{l}\text { Main characteristics: voluntary } \\
\text { (particular elements can be } \\
\text { used voluntarily, joining can } \\
\text { be voluntary). } \\
\text { Organizational principle: } \\
\text { optional (independent, } \\
\text { free use of time). }\end{array}$ \\
\hline Changeability & $\begin{array}{l}\text { Cannot be changed in } \\
\text { regard to people or } \\
\text { framework. }\end{array}$ & Changes over time. & $\begin{array}{l}\text { Relationships can be freely } \\
\text { ended and started. }{ }^{12}\end{array}$ \\
\hline Mutuality & $\begin{array}{l}\text { None (the relationships } \\
\text { are mainly non } \\
\text { reciprocal). }\end{array}$ & None. & Yes. $^{13}$ \\
\hline Presence of authority & $\begin{array}{l}\text { There is a } \\
\text { predetermined } \\
\text { authority in the form of } \\
\text { a natural hierarchy } \\
\text { (parents); accepting } \\
\text { discipline and rules is } \\
\text { not voluntary. }\end{array}$ & $\begin{array}{l}\text { There is a predetermined } \\
\text { authority in the form of } \\
\text { an artificial hierarchy } \\
\text { (teachers); accepting } \\
\text { discipline and rules is not } \\
\text { voluntary }{ }^{14} \text {. }\end{array}$ & $\begin{array}{l}\text { There is neither a } \\
\text { predetermined authority, nor a } \\
\text { predetermined hierarchy }{ }^{15} \text {; } \\
\text { accepting discipline and rules } \\
\text { is voluntary }{ }^{16} \text {. }\end{array}$ \\
\hline $\begin{array}{l}\text { Appearance of } \\
\text { environment }\end{array}$ & $\begin{array}{l}\text { From birth } \\
(0-\ldots \text { years }) .\end{array}$ & $\begin{array}{l}\text { From school } \\
\text { (kindergarten) } \\
\text { (3-6 years). } \\
\end{array}$ & $\begin{array}{l}\text { The need for its elements } \\
\text { arises approx. at the same time } \\
\text { (8-12 years). }\end{array}$ \\
\hline $\begin{array}{l}\text { Level of } \\
\text { institutionalization }\end{array}$ & More institutionalized. & Institutionalized. & Less institutionalized. ${ }^{17}$ \\
\hline Relations & Given. & Obligatory. & Optional. \\
\hline $\begin{array}{l}\text { Time spent } \\
\text { (ages 14-16) }\end{array}$ & Approx. 2-6 h. & Approx. 5-7 h. & Approx. 3-9 h. \\
\hline
\end{tabular}

Table 1 Similarities and differences in the socialization environments

\begin{tabular}{|c|c|c|c|c|c|c|c|c|c|c|c|c|c|c|c|c|c|c|c|c|c|c|c|c|c|c|c|c|c|c|c|}
\hline $\begin{array}{l}\text { Socialization } \\
\text { environments }\end{array}$ & 0 & 1 & 2 & 3 & 4 & 5 & 6 & 7 & 8 & 9 & 10 & 11 & 12 & 13 & 14 & 15 & 16 & 17 & 18 & 19 & 20 & 21 & 22 & 23 & 24 & 25 & 26 & 27 & 28 & 29 & 30 \\
\hline $\begin{array}{l}\text { Primary } \\
\text { (family - } \\
\text { relatives) }\end{array}$ & & & & & & & & & & & & & & & & & & & & & & & & & & & & & & & \\
\hline $\begin{array}{l}\text { Secondary } \\
\text { (kindergarten - } \\
\text { school) }\end{array}$ & & & & & & & & & & & & & & & & & & & & & & & & & & & & & & & \\
\hline $\begin{array}{l}\text { Extra-curricular } \\
\text { and familial } \\
\text { activities }\end{array}$ & & & & & & & & & & & & & & & & & & & & & & & & & & & & & & & \\
\hline
\end{tabular}

Table 2 The impact of socialization environments on the individual (in relation to the age)

The literature on socialization environments (see previously) does not say on what basis an environment can be defined as a socialization environment and therefore which environments do not qualify as such; nevertheless it suggests that the intensity of the socialization environment and the autonomy that results from it depend on the following three factors: 


\section{Acta Technologica Dubnicae \\ volume 2, 2012, issue 2}

- The time spent in the socialization environment: most obviously, the individual spends a considerable amount of time in the family and the school, while it can also be ascertained that the time he spends outside these two socialization environments will reach and then supercede (even many times over) this level as he progresses in age (see Table 1).

- The intensity of the time spent in the socialization environment: in this case the intensity refers to the involvement of an individual in the given socialization environment, the depth of their participation and the strength of their ties to this environment. In the family and the school this intensity is by definition very high, with manyfold and deep ties. Authors who have written about the environment outside the family and the school maintain that the aforementioned relationship of an individual is of a similar intensity in the third socialization environment.

- A socialization environment must have its own system of rules and its own principles of participation: as can be seen from the Table 1, the set of rules governing the extrafamilial and curricular environment fundamentally differs from the rules and principles of the socialization environments of the family and the school.

Based on the above mentioned it can be stated that there is a distinctly delineable socialization environment outside the family and the school. Furthermore, with regard to the chronological emergence of this socialization environment in the life of an individual, we propose it to be called the tertiary socialization environment.

This tertiary socialization environment does not form the basis of any profession, since it is not regarded by any one of them as their main focus, especially not with the youth age groups at its centre. The activities related to this environment require knowledge that is not covered by other professions; thus, the mission of the youth profession can gradually be outlined: to render unsubstitutable support to the members of the youth age groups in becoming citizens responsible for their own actions and their communities primarily in the tertiary socialization area but in (re)socialization emergency situations in all the socialization fields.

Although the extracurricular and extrafamilial environment includes not only free time but also other obligatory activities - e.g. official affairs, medical check-ups - the amount of the time spent on these is not significant, and, broadly speaking, they can be linked to the tertiary as well as to other environments (medical check-ups at the workplace, medical tests for employment, or annual screenings, applying for a birth certificate, certificate of a good character required for university admission, or various affairs at public utility works, etc.). Z. Vajda - É. Kósa (2005) claim that the research into socialization focuses mainly on families, schools and peers (and less on broader spheres of interaction, primarily on mass communication). Although they include the Internet in mass communication it can be disputed in many respects (activity - passivity, individual - mass, etc.).

In the present context it is not so essential to establish whether mass communication can be regarded as an autonomous environment (cf.: cultural identity is now not formed in classrooms but in TV studios (György, 2002). The situation is somewhat similar to the differences between theories pertaining to the sectoral division of society, where the three-sectoral (state, market, non-profit) approach clashes with the four-sectoral theory (state, market, non-profit, household), although the existence of the non-profit sector is debated by none of them. Here we have a similar case: the existence or non-existence of a quaternary environment does not affect the existence (or nonexistence) of the tertiary environment. What is more, we can toy around with the idea that the "official world" (offices, healthcare, etc.) can be proposed as a quinary socialization environment in regard to its impact, although not in regard to temporality. The impact of this environment cannot be underestimated (see the public conditions in Hungary), and indeed: this element appears to come after the other four, as the fifth one. 


\section{$3 \quad$ Youth work, the youth profession ${ }^{18}$}

In the following part of the study a model will be presented to systematize youth support activities. The model is based on the direct (concrete) or indirect (abstract) nature of activities involving individuals/communities. In the focus of the model is an individual (or the community he belongs to) carrying out the youth activity (in this study the youth activity comprises activities outside the educational system, conducted on a voluntary basis in one's free time to help youth groups). The innermost layer of the structure is formed by activities carried out directly by individuals (communities). The middle layer contains activities that are only indirectly connected with the individuals (communities) and "merely" provide an organizational structure creating synthesising theories for them. The outermost layer represents a horizontal youth approach and contains borderline areas, professions linked with youth work.

a) Youth work is defined as the sum of activities realised through the interaction between youth groups and actors directly in contact with them. It is social, community and personal development and empowering work aimed at solving the problems specific to the examined age groups and facilitating their social inclusion partly based on their active participation and partly on the special tools of the youth profession. The key words of youth work are: exploration of self-image, self-knowledge, self-activity, community dialogue, group socialization dealing with challenges, free time activities, informal learning. Youth work is predominantly linked with factors directed at development (personality, community, group, regional, settlement development...) in which the positive signs, the promise and the potential of support, modernization and renewal are inherent and also indicated by key words such as empowering, encouraging, and inclusion. Youth work entails notions like solidarity, the active ability and skill to accept differences (and within that empathy). The range of its services differs from those offered by businesses in that they are (theoretically) generally available, low-threshold services without financial or other requirements.

b) Youth profession: the middle section of youth activities which, through their content and methodology, can facilitate indirect youth work. It is a sum of activities at higher levels of abstraction aimed at providing the "background" for youth work.

c) Youth field: any activity associated with youth groups, primarily within the activities of other sectors (education, social work, culture, economy, etc.), and aimed at the development of areas ranging from the development of family planning competences, support schemes, labor market and entrepreneurial competences, through child benefit schemes and learning, to youth media and culture (representing a horizontal approach).

Figure 1 Structure of youth activities

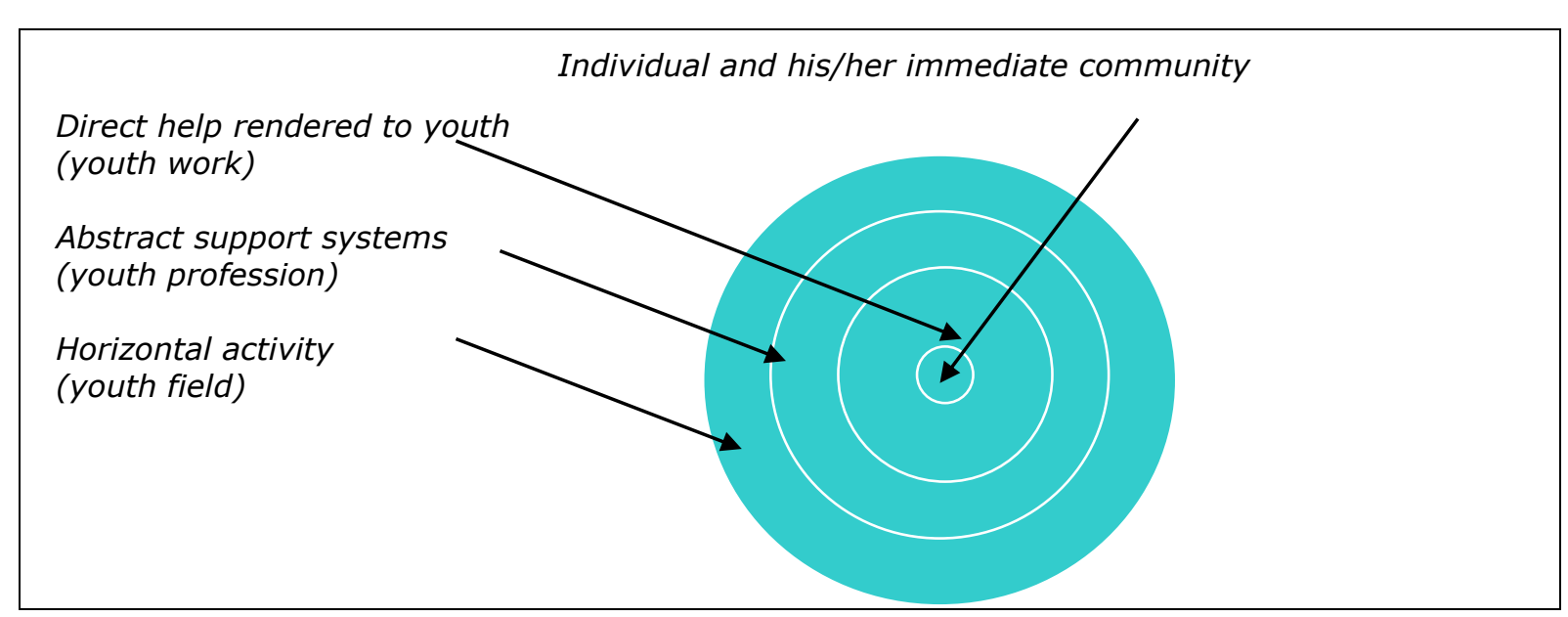




\section{Acta Technologica Dubnicae \\ volume 2, 2012, issue 2}

It has been obvious that the tertiary socialization environment is not a highlighted aspect of any profession, since it is not regarded by any of them as being specific to its profile, especially not in regard to youth groups. Activities related to the youth require knowledge that is not available in any other profession; thus, the task of the youth profession can be outlined: to render support - that cannot be substituted by any other - in regard to the process of young people becoming citizens responsible for themselves and their communities, primarily achieved through the development of the tertiary socialization environment and, in a (re)socialization emergency ${ }^{19}$, of all socialization environments.

Youth work is a collective term aimed, in part and as a whole, at helping young people in the process of growing up. Two important aspects must be focused on in regard to youth work targeting these age groups: the participants and the areas. Direct and indirect youth work will be examined from both aspects, since the overall standard of youth work depends on how successfully the various activities and groups of activities strengthen one another and thus facilitate the process of growing up. Numerous synonyms are known in everyday communication for the terms and expressions (e.g. youth profession, youth work) used in the youth field.

The phrase 'youth work' offers a wide range of interpretations, regardless of the fact whether the given uses are linked to one another; however, to some extent each one concerns young people's growing up. Therefore, the term must be properly defined first. Many people associate youth work with some concrete job done by a young person as if at a workplace (youth work agencies target at this area). Moreover, in an everyday sense, youth work is done by the official working for a local government if he deals with tasks related to youth age groups. In the commonly used meaning of the term doctors, teachers, training officers, youth workers, swimming coaches also do youth work. There are a lot of people in the field engaged in a lot of activities, working in many areas, with entirely different qualifications and ideas, as well as fundamentally different methods and objectives. Indeed, young people who come into contact with them can also completely differ from each other, in regard to age, life situation, level of maturity, etc. People in the youth field only have two things in common: the role they play in the lives of young generations is in some way connected to the growing up, and their work is characterized by the activity and concrete actions. Strange as it may sound, only these can link a grandmother reading a bedtime story to his grandchild and a child's dentist.

The definition previously used in this section about the youth profession can be made more accurate by establishing which three groups youth activity is related to:

- directly to the youth age groups - youth work;

- to the community of youth professionals and the youth sector of the state (government, local government, etc.) - youth profession;

- to the borderline areas of youth activities that do not form part of the youth profession but are affiliated with it; horizontal approach to youth - youth field (i.e. in our model youth culture, health, inhabitance, allowances, education, family, employment, etc., all belong to the horizontal youth area).

Regarding the areas of youth work, focus will be placed on those areas in which activities are directly aimed at the young generation and their members. As regards the youth profession, it contains the segments in which work carried out for young people is more abstract than the previously mentioned direct work, i.e. it is at a higher level of abstraction. 
Figure 2 Youth work, youth profession and horizontal youth activities

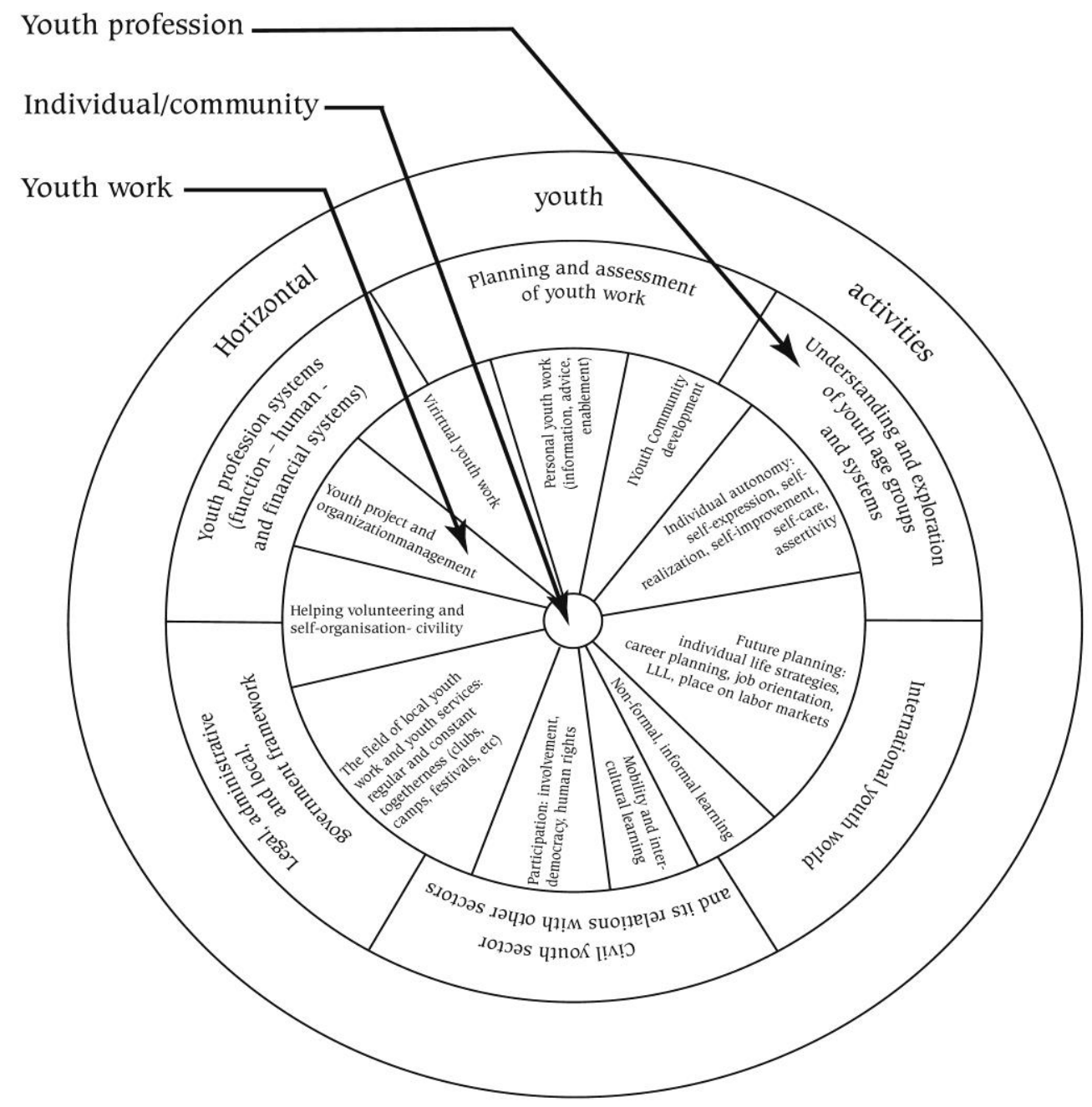

\section{$4 \quad$ Areas of youth work}

\section{Informal learning and youth activities}

In the triangle of formal, non-formal and informal learning methods, the latter one appears the most characteristically in the youth area. Informal learning is a kind of learning in which the learning process as such is lost in other types of activities and contents that are not planned and assessed. Among others, edutainment (learning through entertainment) belongs to this category, but the knowledge acquired through the experience is also a form of informal learning. There is a close connection between informal learning and indirect (bottom-up) learning, in which tasks are the sources of impact, conditions are like relations and interrelations between pupils, and interactions are the primary means and mediators of behavior patterns (e.g. mutual check, mutual help, etc.). Besides informal methods, the youth field applies non-formal and, in our case, formal pedagogical methods. (Accordingly, e.g. organizing leisure programs can only be regarded as youth work if it fits into a pedagogical process.) This segment is a special transition between the group-oriented approach of community development and the individual approach of youth assistance, since the activities are conducted in groups but are aimed at the development of the individual. 


\section{Local youth work-institutionalised youth services}

Youth services are generally, although not exclusively, (rendered to the) public services aimed at catering to the needs and other manifestations of different age groups of the generations growing up and expected to fulfil specific professional requirements (e.g. legal, labor market, psychological, drugrelated, etc.). In addition, they must be relevant to the youth, i.e. the services not only have to meet the professional criteria of a given area but also include developmental tasks, or elements of socialization (preparing young people for adulthood). Thus, the youth services must effectively satisfy both demands. This area involves everything that facilitates the understanding of social processes through the services (and not directly) and encourages the active participation of youth age groups in these, empowering them to become active shapers of their life. Youth clubs, playgroups, adolescent centres, youth offices, youth information centres, festivals, camps, etc. are all regarded as youth services.

\section{Personal youth work}

Acquiring basic self-knowledge and peer knowledge and its development are quintessential to any assistance activity. The methodology of youth advisory activity has person to person relationships at its focal point - providing information, advice and assistance - determining assistance models, conflicts, conflict management, etc. Youth work is mainly built on communication, factors that facilitate or hinder it, and personality development methods. Although, in general, help is provided for and comes to fruition in a community, the emphasis in this area is still on person-to-person interaction ${ }^{20}$.

\section{Youth community development}

Living in a society we all partake in various organizations, groups, associations and - if lucky communities that represent quality. It is generally accepted that youth work can be done efficiently and effectively mainly in communities. One of the reasons why youth work is built on communities is that, besides its multifariousness, one of its main objectives is to ensure and develop the passing on of social and cultural values. The area deals with the youth elements of this, which include peer assistance and other methodologies. In dealing with youth groups, their establishment and development, special emphasis is placed on the inner mechanisms of youth communities and their development, as well as community development procedures implementable among the youth ${ }^{21}$.

\section{Youth project and organization management}

This area involves project activity specifically for youth communities. The segment is aimed at handling the youth aspects of stakeholder management, project cycle management and project area management (project focus, integration, time, cost, human resource, quality, communication and risk management). In another approach, it is the management of youth projects to the benefit of youth age groups, the initiation, planning, organization, implementation and direction of programs organised for youth (various events, festivals, camps, training courses, publications, etc.) as well as checking their realisation and closing them.

\section{Mobility and intercultural learning}

The balance of a given society largely depends on the relationship between the majority and minority cultures and the personal aptitude of the representatives of given groups. Key elements of mobility and intercultural learning are the assumable and real presence of diversity and pluralism, their acceptance by the wider and smaller communities involved, as well as the existence and necessity of learning openness and acceptance. Intercultural learning means more than cultural, national, ethnic and religious sensitisation but also the acceptance of "everyday othernesses" such as disabilities, sexual differences and identities, ideological differences, as well as the age, generation or even geographical differences that define the given stage of life of an individual. 


\section{Voluntariness}

Voluntariness is the self-activity of citizens based on the solidarity between the members of society: it is an action freely rendered to people (not relatives), their communities or others, without expecting compensation. Cooperation with youth groups and organizations forms part of youth work. In certain cases it facilitates youth public life from the individual initiative all the way to the establishment of an organized entity. It is, therefore, important to mention altruism, youth cooperation, assistance to youth self-organization and the nature of voluntariness.

\section{Virtual youth work}

The opportunities provided by the information society fundamentally transform the notions of social environment, youth community space, youth social networking, etc. Virtual youth work addresses the following issue: in what regard can youth age groups be regarded as occupying a special position in virtual space (primarily but not exclusively on the Internet) (Tapscott - Williams, 2006; Tapscott, 2008). The area also deals with the changes of youth culture and youth communities (and their characteristics) organized in virtual space.

\section{Participation: involvement, democracy, human rights}

This means all the activities carried out by youth communities and organizations to involve young people in the lives of the local communities; for example, to promote youth participation in the lives of settlements/regions etc. (organization and operation of local youth governments, youth representation), activities carried out by formal youth organizations and non-formal youth communities, assistance rendered to youth by other organizations and professionals, as well as other activities aimed at the better interiorisation of democracy and its institutions, and activities promoting the education, practice and reception of human rights etc.

\section{Future planning (life strategies, career planning, LLL)}

This involves everything that concerns "not the present but the future": life strategies, personal and vocational planning, learning competences necessary for employment, career planning, etc.

\section{Individual autonomy: self-expression, self-realization, self-improvement, self-care, assertivity}

This area is mainly concerned with the individual and identity: how responses should be expressed, how to respond to impulses, how to organize, express and develop oneself, one's body, mind and spirit. Self-expression and assisting others in their development can be the most effectively done while people are still young.

\section{$5 \quad$ Areas of the youth profession}

\section{Legal framework of youth activities}

This area primarily covers youth legislation (specifically applicable to the youth field and adopting a youth approach across its entire volume) and justice, its examination and implementation. It defines child rights (limitation of autonomy, assertion of legal capacity), youth rights (operation of special support systems) and youth law (one of the principal arguments for the autonomy of the youth field is the need for a separate legal framework). The legal framework of youth activities examines the position of youth in law: regulations pertaining to youth must pervade the entire legal system. It deals with the theoretical (constitutional) starting points of the legal approach taken to children, i.e. the 


\section{Acta Technologica Dubnicae \\ volume 2, 2012, issue 2}

fundamental characteristics of legal relations, the consideration of age-specific characteristics of individuals otherwise having the same legal capacity, the restriction of exercising rights and enhanced legal protection as well as with the rights and obligations of those working with children (youth workers). The legal framework for youth activities raises awareness regarding the state's obligations in connection to children's rights which are stipulated by the constitution and international agreements and relevant laws. The area also addresses issues that have not been defined and settled legally (e.g. what happens, what is the legal assessment in the case of adolescents taking on public roles; is the youth worker regarded as a person of public authority, i.e. if someone confides in him/her that he/she smoked a joint, what is his/her legal duty, is he/she obliged to report the case?). The problem of the youth act also forms part of this area, and although there is no legal obligation to draw up such an act, its existence would indicate the state's commitment and systematic approach to the situation of the youth. Borderline areas that are not specifically part of the youth field but play a significant role regarding the legal regulation of the area (organizations, legal regulation of civil framework, procedures, etc.) also fall within the legal framework of youth activities.

\section{Study and research of youth age groups}

This area essentially examines the social layers of young people, stratification, the local cross-sections of the youth, as well as small and big groups organized along specific values, model patterns, freetime and work. Important disciplines that form part of the study and research of young age groups include cultural anthropology, ethnography and political sciences. This area reviews the various youth research activities from the preparatory work required by projects, collection and processing of the data, through their interpretation and to their systematic study-level presentation and publication. This segment also reviews the methodology of youth research, which, in addition to its sociological foundation, applied, already at the very beginning, various psychological approaches and some of their tools, the approach and study methods of social psychology, combining the research methods used in sociology, management theory and pedagogy. The development of methods determined by the objectives of projects and comparative analyses belong to such research.

\section{Planning and assessment of youth work}

This area covers forming of the strategy and related action plan, as well as their monitoring. Youth strategy is the long-term (10-20-year long) arrangement of actions of a given community, society or large social group in regard to the youth, according to specific objective(s), as well as the designation of resources for its implementation. The content of the area pertains to young age groups, although truly "usable" strategies and action plans cannot disregard the adult population. Action plans elaborate the actions to be implemented in a short term (2-4 years), as inferred from the strategy, and designate the sources and people in charge. Monitoring examines the rationale behind the implemented measures and compares them with the plans. However, strategies and action plans are not only "youth" because they focus on the youth but also because young generations, communities and organizations actively participate in their formulation and implementation.

\section{Youth systems}

This area deals with the definition and operation of the public tasks of the youth, determines their indicators and evaluates them. The area also deals with the financial systems (from the tender system to the governmental development activity) and human systems (training system, youth networks, etc.).

\section{International youth activity}

This area analyses the supranational cooperation in regard to youth activities. Youth organizations, government structures, and research processes have grown beyond their initial frameworks and have introduced services, opportunities and challenges that can only be realised through the broad-based cooperation extending beyond national borders. The area deals with the objectives, content, methods 


\section{Acta Technologica Dubnicae \\ volume 2, 2012, issue 2}

and forms (e.g. networks and cross-border cooperation) of international youth activity, the framework institutions, organizations, their operation, interdependence, structure, important documents, support programmes, primarily - but not exclusively - in a European dimension.

\section{Civil youth sector and its relations with other sectors}

The most important element of the non-profit sector is that in regard to its fundamental attributes it differs from the state and economic organizations (in addition to the traditional division of state and economic, the third one is the so-called non-profit sector). The non-profit sector is distinct from the state (it has no functions of public authority) and the economy (it is not driven by making a profit), and it most often comprises civil organizations, i.e. organizations established by volunteers and operated on a self-active basis. The area focuses on the rules and phenomena of the youth segment of the civil sector, and the youth work conducted in the segment.

This area involves the strategies and techniques regarding the representation of the members of a given community, organisation, government or local government organisation, etc. and the assertion of the interests of youth age groups (or a part of them), as well as the communication of these strategies and techniques and also its special characteristics in the youth segment. Youth representation involves the analysis, discussion and communication of situations, problems, action plans and consequences carried out by the members and representatives of youth age groups in order to impact decisions affecting the youth and influence decision-makers - both individuals and institutions - to the benefit of the youth. The members and representatives of youth age groups can be local non-formal communities and their leaders, local or higher level - regional, county, nationwide, international formal organizations and their leaders, as well as forums of cooperation affiliated with certain institutions (e.g. student government of public educational institutions, youth divisions of company trade unions). The area of youth representation also includes institutions and actors with a leading role in the youth field and the authority to impact it, and entails cooperation with decision-making bodies, youth dialogues, and preparatory work carried out before decision-making, the role of control, as well as lobbying for youth interests in the profit or non-profit sector alike.

\section{Horizontal youth activity}

We did not divide the so-called horizontal youth activities into parts, since different social systems, countries, and approaches require different divisions they deem sensible and compliant with their own social philosophy (since horizontal youth activities concern the relationship between the youth sector and other sectors). The following division has started to take shape in Hungary:

- youth and formal education,

- youth and family,

- youth and culture, consumption and media,

- youth and the world of health,

- youth and the world of work,

- youth and politics,

- youth and deviance crime,

- youth and poverty, segregation, marginalization,

- youth and those living with disabilities,

- youth and liveable environments,

- youth and europeanness,

- youth and national identity. 


\section{Summary}

Many sociologists and pedagogues deal with those scenes, periods of life and phases in which socialization occurs. However, up until now, no comprehensive study approached the extrafamilial and extracurricular scenes of socialization based on their shared characteristics. The present study was aimed at describing the tertiary socialization environment in regard to the social time of young people and the groups of impacts affecting them.

The tertiary socialization field is not the main focus of other professions, and related activities require knowledge which other professions do not fully cover. That is why we can outline the mission of the youth workers: to work with young people (people and communities) in the tertiary socialization field.

We made an attempt to classify youth activities in the tertiary socialization environment from the perspective of the individual (community), applying this approach to youth work, the youth profession and horizontal youth activities. We divided youth work into eleven and the youth profession into six areas, while we did not divide horizontal youth activities.

\section{Literature}

ALPÁR, Z. - LUX, E. - PÁL, M. - POPPER, P.: Legfeljebb elválunk - az élet dolgai. Budapest: Saxum, 2009.

BAGDY, E.: A csoport specifikus hatótényezöi: a csoportdinamikai történések. In: Konfliktuspedagógiai szöveggyüjtemény. Veszprém: Veszprémi Egyetemi Kiadó, 1994, p. 5358.

BODÓ, C.: Nyelvi szocializáció és nyelvi tervezés a moldvai magyar-román kétnyelvü beszélöközösségekben. www.adatbank.transindex.ro/html/cim_pdf436.pdf. [2010.03.01]

BODONYI, E. - BUSI, E. - HEGEDÜS, J. - MAGYAR, E. - VIZELY, Á.: A gyakorlati pedagógia néhány alapkérdése. Budapest: Család, Gyerek, Társadalom, Bölcsész Konzorcium, 2006.

CZEGLÉDI, S.: Az ifjúsági nyelv szóhasználati jellegzetességei egy veszprémi felmérés tükrében. Veszprémi Egyetem Angol Tanszék, kézirat (manuscript).

CSEPELI, G.: Szociálpszichológia. Budapest: Osiris Kiadó, 2006.

DEMETROVICS, Z. - PAKSI, B. - DÚLL, A. (eds.): Pláza, ifjúság, életmód - egészséglélektani vizsgálatok a fiatalok körében. Budapest: L'Harmattan Kiadó, 2010.

DUPCSIK, C.: Magyar Virtuális Enciklopédia Szocializáció cikkszó. www.enc.hu/1enciklopedia/fogalmi/szoc/szocializacio.htm [2010.03.01]

FURLONG, A. - STALDER, B. - AZZOPARDI A.: Vulnerable Youth: perspectives on vulnerability in education, employment and leisure. Strasbourg: Council of Europe, 2000.

GÁBOR, K. (ed.): Társadalmi átalakulás és ifjúság. Szeged: Belvedere Kiadó, 2000.

GÁBOR, K.: Az ifjúsági kultúra és a fiatalok társadalmi orientációs mintái in. Civilizációs korszakváltás és ifjúság. Budapest: Miniszterelnöki Hivatal Ifjúsági Koordinációs Titkárság, 1992.

GÁBOR, K.: Társadalmi egyenlőtlenségek. www.ifjusagsegito.hu/belvedere/tarsadalmi_egyenlotlensegek.pdf [2010.03.01]

GIDDENS, A.: Sociology. UK: Polity, 2006.

GYÖRGY, P.: Előszó. In: Buckingham, D.: A gyerekkor halála után - Felnőni az elektronikus média világában. Budapest: Helikon, 2002.

HERVAINÉ SZABÓ, G.: A globalizáció és az ifjúsági bandák kapcsolata. In: Bábosik, I. - Torgyik, J. (ed.): Az iskola szocializációs funkciói. Budapest: Eötvös Kiadó, 2009.

KISS, J.: Társadalom és nyelvhasználat. Szociolingvisztikai alapfogalmak. Budapest: Nemzeti Tankönyvkiadó, 2002.

KÓSÁNÉ, O. V.: Szocializációs zavarok és az iskola. In: Gáti, F. - Horányi, A. - Kósáné, O. V. (eds.): Szemelvények a hazai gyermek - és ifjúságvédelem irodalmából. Budapest: Tankönyvkiadó, 1989. 
KÓSÁNÉ, O. V. - MÜNNICH, I.: Szocializációs zavarok-beilleszkedési nehézségek. Budapest: Tankönyvkiadó, 1985.

KOZMA, T.: Bevezetés a nevelésszociológiába. A nevelésszociológia alapjai Tankönyvkiadó. Budapest: Nemzeti Tankönyvkiadó, 1999.

MÁTÓNÉ SZABÓ, C.: Az ifjúsági szubkultúrák szocializációs hatásainak iskolai kezelése. In: Bábosik, I. - Torgyik, J. (eds.): Az iskola szocializációs funkciói. Budapest: Eötvös Kiadó, 2009.

MURÁNYI, I.: Identitás és előitélet. Budapest: Új mandátum Kiadó, 2006.

MUSGRAVE, P. W.: The Sociology of Education. London: Routledge, 1979.

NAGY, Á.: Keresik életük értelmét? Olvasás-könyvtár-szocializáció. Budapest: OSzK KMK, 1991.

NAHALKA, I.: Túl a falakon: az iskolán kivüli nevelés módszerei, ELTE BTK, Neveléstudományi Intézet. Budapest: Gondolat Kiadói Kör, 2003.

PARSONS T. - BALES R. F.: Family, socialization and interaction process. Glencoe: Free Press, 1995.

PIAGET, J.: Sociological Studies. London: Routledge, 1995.

SOROKIN, P. A.: Social and cultural mobility. New York: Free Press, 1959.

SZABÓ, E.: "Nagyobb lesz az ember, ha kicsit dumásabb" A börtönszleng használók véleménye nyelvváltozatukról. In: Magyar Nyelvjárások, Debreceni Egyetem Magyar Nyelvtudományi Tanszék évkönyve, Debrecen, 2003. http://mnytud.arts.klte.hu/szleng/tanulmanyok/73szaboe.doc [2010.03.01]

SZABÓ, A. - BAUER, B. - LAKI, L. (eds.): Ifjúság2000 Tanulmányok. Budapest: Nemzeti Ifjúságkutató Intézet, 2002.

SZABÓ, A. - BAUER, B. (eds.): Ifjúság2004 Gyorsjelentés. Budapest: Mobilitás Ifjúságkutatási Iroda, 2005.

SZABÓ, A. - BAUER, B. (eds.): Ifjúság2008 Gyorsjelentés. Budapest: Szociálpolitikai es Munkaügyi Intézet, 2009.

SZAPU, M.: A zürkorszak gyermekei: mai ifjúsági csoportkultúrák. Budapest: Századvég, 2002.

SZÉKELY, L.: Virtuális ifjúsági munka. In: Földi, L. - Nagy, Á. - Járosi, É. (eds.): Ifjúságügy ifjúsági szakma, ifjúsági munka, Módszertani kézikönyv. Budapest: Mobilitás-ISzT-ÚMK, 2010.

SZÉKELY, L. - RAB, Á. - NAGY, Á.: Virtuális ifjúsági munka. In: Nagy, Á. (ed.): Ifjúságügy Ifjúsági szakma, ifjúsági munka. Budapest: Palócvilág - Új Mandátum, 2008.

TAPSCOTT, D.: Growing up digital. New York: McGraw-Hill, 2008.

TAPSCOTT, D. - WILLIAMS, A. D.: Wikinomics. How Mass Collaboration Changes Everything. New York: Portfolio, 2006.

TRENCSÉNYI, L.: Az iskola funkcióiról a nevelési intézmények történeti rendszertanában. In: Kiss, É. (ed.): Pedagógián innen és túl. Pécs: Veszprém, 2006.

TRENCSÉNYI, L.: Nagy Ádám Ifjúságügye. In: Új Pedagógiai Szemle, 2009, n. 2.

VAJDA, Z. - KÓSA, É.: Neveléslélektan. Budapest: Osiris, 2005.

VÁRINÉ, Sz. I..: Bevezetés. In: Somlai, P. (ed.): Álláspontok a szocializációról, Szociológiai füzetek. Budapest: Oktatási Minisztérium, 1975.

VUKOVICH, G.: Szocializáció. In: Nagy, K. (ed.): Szociológia. Budapest: Typotex, 2006. 


\section{Acta Technologica Dubnicae \\ volume 2, 2012, issue 2}

\section{Notes}

1 In the present case socialization is defined as the process of acquiring knowledge and skills enabling the individual to become a member of society. During this process the individual acquires knowledge of himself/herslf and his/her society, acquires the rules of living together as well as the possible and expected behavioural patterns (Bagdy, 1994). Education is aimed at influencing this process, while socialization can be an unconscious process. Therefore, in our definition socialization is a broad category: it is not restricted to a closely delineable process but rather a wide range of phenomena (from formal socialization agencies to non-formal actors) (Vajda - Kósa, 2005), where the socialization process is not only the result of conscious learning but can occur via hidden mechanisms (Pecheron, in Murányi, 2006). Socialization, one of the notions shared by psychology and sociology, and in this sense is not identical with social development, part of which is the formation of the individual with a distinct emotional world and individual behaviour.

2 Although the socialization agencies and social mobility share many characteristics, in the present study these agencies are not defined as areas of mobility (about social mobility, see: Sorokin's studies).

These agencies of course do not trigger mechanic responses but rather urge the individual to participate in a particular framework in his/her social practice (Giddens, 2006).

We first see the relations between roles, symmetrical and asymmetrical relationships here, and we learn the status value of different roles, the hierarchy of statuses and the principle of mutuality in the family. The socialization functions of the family: care and protection (learning love as the primary social emotion), providing interaction space - providing models and learning roles, acquiring the fundamentals of the I, the I system, and inner control functions (formation of systems of stimulating and inhibiting action, delaying, frustration tolerance and the ability to control oneself in receiving reward and punishment) and the foundations of the order of communication (verbal and non-verbal communication and their harmony).

These groups of various sizes (school classes, gangs, associations, clubs, etc.) contain individuals with shared interests and represent typical social patterns, themes as well as a relatively homogenous language and style.

P. W. Musgrave (1979) explores the areas of work and professions. In his view, the first stage of career socialization is determined by learning the occupational roles linked to the system of careers and after every decision the repertory of roles decreases since the range of available opportunities is narrowing. P. W. Musgrave (1979) discusses professional socialization in detail, the developmental stages of which include, firstly, the (concealed) learning of the roles of preliminary professional socialization (attainment of career knowledge), followed by entering a professional field, stepping onto a career path, career expectations and reality, and, finally, real professional socialization begins when the individual's final role behaviour and meeting the requirements of the given career is formed. For P. W. Musgrave (1979) tertiary socialization emerges when an individual changes his/her career or activity, but since this is only a coincidental overlap of terms, we will not deal with this area in detail.

In this division L. Trencsényi only includes conscious actors (not denying the existence of "spontaneous" socialization effect).

The delineation of this environment is necessitated by theoretical (does extrafamilial and curricular socialization have shared motives, elements and a foundation that link them into a distinct category with shared characteristics) and practical reasons (establishing the basic statements of the youth professions).

Free time for youth is also a trial of adulthood: it is a time of autonomy, self-management and selfrealization where multiidentity manifests itself most visibly. Due to the cyclical nature of a year, the following types of free time activities can be examined:

a) free time on weekdays (typically afternoons);

b) free time at week-ends;

c) free time during holidays (especially in summer). 


\section{Acta Technologica Dubnicae \\ volume 2, 2012, issue 2}

Free time during weekdays, week-ends and holidays can be described based on the results of free time and youth research (Demetrovics et al., 2010; Szapu, 2002; Szabó-Bauer, 2002, 2005, 2009; Gábor, 2000; Gábor, www.ifjusagsegito.hu; Nagy, 1991, etc.):

a) free time during weekdays: watching TV, listening to music, "hanging about", going out to places of entertainment, shopping (consumption), going to shopping centres, entertainment in general, going to the cinema, studying and home work, computer and internet games, time spent together with friends or peers in a community or organization (sport, culture or art, student body, local government body, church, civil/youth organization), reading, doing sport or dancing, raising children, non-computer games, cultural programs: theatre, concert, exhibition, restaurant, café, pub, other activities.

b) free time at weekends: same as during the weekdays, plus going to a disco, house party, trips, other activities;

c) free time during holidays: same as free time at weekends, plus going on holiday with friends, with family, with partner, alone, other activities.

In these periods of time the activities can be divided into two main groups based on the intensity of the activity: there is a strong distinction between functional, physically, intellectually and emotionally demanding free time activities (shopping, meals) and non-functional, passive reception (hanging about). (About the shopping centre as social space, and about functional and non-functional free time activities, see: Demetrovics et al., 2010).

Peer groups, without a predetermined hierarchy of people with equal rank, the world of shopping centres, the Internet, the media and small community interaction, etc. Large institutional systems of education (work) and family affairs are unable to substitute the predominantly voluntary and self-organised third socialization environment, and it is not their task either.

About peer groups and more about globalization, see: Hervainé, 2009.

Csepeli, 2006.

"If we examine the world of youth interaction, we must see that the principle of mutuality cannot be practised in any other context" (Csepeli, 2006, p. 406).

There are attempts (e.g.: Nahalka, 2003) to introduce extracurricular developmental activities into the classroom, however, these do not go beyond the traditional approach to roles, with a teacher playing the key role, and do not provide the opportunity for real community roles to be formed. The tertiary socialization environment is different from school exactly because the roles develop in relation to the forming community.

For more about authority in the family and the school, see: Vajda - Kósa, 2005, about peer groups Csepeli, 2006; Piaget, 1995.

Csepeli, 2006.

Cf. disco dance floor vs. shooting association. The peer group falls outside the institutionalized social network (in our case institutionalized constitutes an objective existence independent of the will of the group members). Adopting an extreme approach we could say that formal groups play an essential role by carrying out activities directly beneficial to the society (e.g. work), while informal groups play a similarly essential role by engaging in activities directly beneficial to the individuals (e.g. games, leisure time, entertainment) (Csepeli, 2006), although the borders between these two groups are becoming less and less defined. The institutions of a consolidated society try to "tame" initiatives organized outside the official institutions with varying degrees of success (Trencsényi, 2006).

18 The youth paradigm is tossed about like Charon's boat: although it can be primarily regarded as an autonomous pedagogical discipline, it can form part of sociology, can be seen as a politological entity, youth work, partly social work and partly a pedagogical activity. Being an autonomous entity it is supported by the very fact that it does not fully form part of any one science or profession.

More about the decomposition of the primary socialization environment, see e.g.: Alpár et al., 2009; the problems within the secondary environment, and primarily about behavioral issues and learning 


\section{Acta Technologica Dubnicae}

volume 2, 2012, issue 2

difficulties, see: Kósáné, 1989; Kósáné - Münnich, 1985 (although only in relation to its solution within the school).

It is not age (or age difference) that plays the main role in the counselling interview but that the helper should not have any selfish motives in his/her relationship with the one helped during the period of the helping relationship. (Here anything that did not form part of the personality of the helped person at the outset or anything that was initially and remained the monopoly of the helper can be regarded as selfish, even the most positive manipulation by a priest, doctor, psychologist, teacher, etc. in the counselling interview is forbidden. This requirement constitutes a problem because even today the experts working in the area of the so-called helping professions unquestionably regard themselves as the knowers in the counselling interview, thus establishing an asymmetrical relationship of roles and excluding the chance for a symmetrical interpersonal relationship. Helpers only have the right to bring to the surface the inner "powers" of the person they are helping and let these powers move into action. Helpers must also be fully aware of the limitations of their own competence.) Moreover, it is important that helpers know exactly up to which point an interview is successful and effective but does not overstep the limit by interfering in the others' life (keeping a symmetrical relationship, and staying within the familiar stranger status). Situations requiring medical treatment and help rendered to people in a psychologically critical condition do not fall within the parameters of helping relationships, only those who need temporary help in a given situation and under given circumstances, e.g.: if those helped need information and, facts or applicable procedures they do not know about; they need help to be able to face their real situation, knowledge, competences, and opportunities; they need to be "released" from the various consequences of pangs of conscience or need help to let the accumulated excess emotions and anger be "purged" from their system; need help to recognise their values and powers, achieve a positive self-evaluation, confirmation and support; or they need help with (psychological) cramps resulting from misconceptions, false beliefs, and misunderstandings. The helping relationship is always based on a request, is always individual and unique. (In an ideal case, the request is formulated, but often the potential helper has to decide if the communication conducted with him/her contained the element of a request.) Taking on the role of a helper is also always a matter of the free, personal decision of the potential helper. The helping relationship occurs within the framework of a kind of contract concluded for the duration and aimed at the concrete subject of the relationship even if this contract is unspoken.

The more communities the members of the youth age groups actively participate in, the more they strengthen the local and ultimately the entire society, especially if they do not forget the patterns learnt as young people when they enter adulthood. Key words of the area: community, community development, guided conversation, voluntariness, animation. This activity providing help for the youth is development aimed at the social environment and the (human) community which young people need to learn to accommodate to and in which they have to be able to find their way, role, self-expression, self-validation, self-representation and the representation of others, as well as assuming responsibility and bearing consequences, i.e. they have to learn decision-making. Self-expression is not the only focus in community development, but the exploitation of the potential and resources inherent in communities enabling them to achieve things they individually could not. Thus, the other focal point in community development is locality, i.e. action and development at local, municipal or regional levels. Community development primarily constitutes the development of the skills of initiative and action, in which citizens play a key role, along with communities and their networks, as well as - depending on the local tasks - community developers, whose encouraging, stimulating, informing, and networking work is often invaluable. Community development has the potential of exploring, complementing and strengthening the resources of a community. Youth community development is also realised at least in two spheres: in an informal world (street workers) and in formalised youth organizations, and in neither of these two areas do the participants have to possess simple attributes linked to a teacher role. Moreover, community development can be studied in a further dimension: there are activities carried out by young people, and those by experts that started working in the field in their youth. 